\title{
STRATEGI PEMBELAJARAN BERBASIS MULTIPLE INTELLIGENCES
}

\author{
Ach Syaikhu \\ IAI AL-Falah As-sunniyyah Kencong \\ achsyaikhu@inaifas.ac.id
}

\begin{abstract}
Education is one indicator that creates civilized humans. Every buman being has basic intelligence that is owned. Where the basic intelligence describes the essence of self or self-wholeness. Without one of these intelligences, a person cannot become a complete and integrated person. Those basic intelligence are: IQ (Intellectual Intelligence), SQ (Spiritual Intelligence), EQ (Emotional Intelligence), and PQ (Physique Intelligence). The learning process is very important as seen by the role of teacher. When the learning process takes place, there is a process of teaching and learning. But this process is not necessarily going well. As for some of the goals that the author wants to achieve in this paper, among others are: 1) To find out what multiple intelligences are 2) To find out a learning strategy based on multiple intelligences. 3) To find out the teaching strategy for multiple intelligences. From this paper, the author hopes that educators will truly be able to master the multiple intelligences that exist in their students. For this reason, teachers must use Multiple Intelligences Research (MIR) to determine the tendency of students' intelligence.
\end{abstract}

Keywords: Multiple Intelligences, Learning Strategy

Abstrak

Pendidikan merupakan salah satu indikator keberhasilan menciptakan manusia yang beradab. Setiap manusia memiliki kecerdasan dasar yang pasti dimiliki. Dimana kecerdasan dasar tersebut menggambarkan hakikat diri atau keutuhan diri. Tanpa salah satunya seseorang tidak dapat menjadi pribadi yang utuh dan terintegrasi. Kecerdasan dasar tersebut yaitu kecerdasan IQ (Intellectual Intelligence), SQ (Spiritual Intelligence), EQ (Emotional Intelligence), dan PQ (Physique Intelligence). Proses pembelajaran sangat penting yang dipengaruhi peran guru didalamnya. Ketika proses pembelajaran berlangsung ada proses guru mengajar dan siswa belajar. Tetapi belum tentu proses ini berjalan dengan baik. Adapun beberapa tujuan yang ingin penulis capai dalam tulisan ini, antara lain 1) Untuk mengetahui apa itu kecerdasan jamak (multiple intelligences) 2) Untuk mengetahui strategi pembelajaran berbasismultiple intelligences. 3) Untuk mengetahui strategi mengajar multiple intelligences. Dari tulisan ini, Penulis memiliki harapan untuk para pendidik agar benar-benar mampu menguasai kecerdasan jamak yang ada pada peserta didiknya. Untuk itu, guru harus menggunakan Multiple Intelligences Research (MIR) guna mengetahui kecenderungan kecerdasan peserta didik.

Kata Kunci: Kecerdasan Jamak, Strategi Pembelajaran

Jurnal Auladuna| 59 
Ach Syaikhu

\section{A. Pendahuluan}

Pendidikan merupakan salah satu indikator keberhasilan menciptakan manusia yang beradab. Pernyataan tersebut sejalan dengan tujuan pendidikan nasional yang tertera pada Undang-Undang Nomor 20 tahun 2003 tentang Sistem Pendidikan Nasional (Sudjiono, 2013) yaitu mengembangkan potensi peserta didik agar menjadi manusia yang beriman dan bertakwa kepada Tuhan Yang Maha Esa, berakhlak mulia, sehat, berilmu, cakap, kreatif, mandiri, dan menjadi warga negara yang demokratis serta bertanggung jawab. Potensi-potensi ini juga membutuhkan daya keahlian dalam bidang kognitif disetiap pengembangannya. Kognitif sangat erat kaitannya dengan potensi pengetahuan manusia yaitu biasa disebut dengan kecerdasan.

Setiap manusia memiliki kecerdasan dasar yang pasti dimiliki. Dimana kecerdasan dasar tersebut menggambarkan hakikat diri atau keutuhan diri. Tanpa salah satunya seseorang tidak dapat menjadi pribadi yang utuh dan terintegrasi. Kecerdasan dasar tersebut yaitu kecerdasan IQ (Intellectual Intelligence), SQ (Spiritual Intelligence), EQ (Emotional Intelligence), dan PQ (Physique Intelligence).

Proses pembelajaran sangat penting yang dipengaruhi peran guru didalamnya. Ketika proses pembelajaran berlangsung ada proses guru mengajar dan siswa belajar. Tetapi belum tentu proses ini berjalan dengan baik. Guru mengajar belum tentu siswanya mendengarkan penjelasan gurunya, bisa saja ketika guru mengajar malah siswanya asyik dengan melamun, tidur, atau bermain sendiri. Menurut Alamsyah, 2016:16 menjelaskan bahwa tidak ada anak yang bodoh, yang ada anak berkemampuan rendah. Penyembuhan akan hal tersebut bisa dilakukan dengan guru yang tepat dan strategi pembelajaran yang sesuai dengan jenis kecerdasan atau gaya belajar dan modalitas belajar anak. Dalam hal ini teori tentang multiple intelligence yang dicetuskan oleh Howard Gardner menjadi salah satu rujukan dalam membangun dan mengembangkan pembelajaran di kelas dengan memperhatikan seluruh kecerdasan yang dimiliki oleh siswa terutama pada tingkat pendidikan anak usia dini (PAUD).

\section{B. Pembahasan}

\section{Kecerdasan Jamak (Multiple Intellegencies)}

Teori Multiple Intelegences (Kecerdasan Jamak) adalah teori yang ditemukan dan dikembangkan oleh Howard Gardner. Ia mulai menuliskan gagasannya tentang intelegensi ganda

60 | Jurnal Auladuna 
dalam bukunya Frames of Mind pada tahun 1983. Gardner (dalam Suparno, 2004:17) mendefinisikan intelegensi sebagai kemampuan untuk memecahkan persoalan dan menghasilkan produk dalam suatu seting yang bermacam-macam dan dalam situasi yang nyata.

Secara umum Gardner memberikan syarat kemampuan yang dapat dipertimbangkan sebagai intelegensi dalam teori intelegensi gandanya, yaitu bersifat universal. Kemampuan itu harus berlaku bagi banyak orang, bukan hanya untuk beberapa orang. Kemampuan itu dasarnya adalah unsur biologis, yaitu karena otak seseorang, bukan sesuatu yang tejadi karena latihan atau training. Kemampuan itu sudah ada sejak orang lahir, meski dalam pendidikan dapat dikembangkan. Ada sembilan intelegensi yang diakui oleh Gardner yaitu intelegensi linguistik, intelegensi matematislogis, intelegensi ruang, intelegensi kinestetik-badan, intelegensi musikal, intelegensi interpersonal, intelegensi intrapersonal, intelegensi lingkungan/naturalis, dan intelegensi eksistensial.

1. Jenis-Jenis Kecerdasan Jamak

a. Kecerdasan Linguistik

Menurut imami (2018:1) kecerdasan linguistik adalah salah satu kecerdasan jamak. Kecerdasan ini dikenal dengan kemampuan seseorang untuk menggunakan bahasa baik lisan maupun tulisan dengan baik dan benar. Mereka cenderung mempunyai keterampilan reseptif auditori dan produktif verbal yang sangat baik. Kecerdasan linguistik sering disebut juga kecerdasan dalam berbahasa.

b. Kecerdasan Logis-Matematis

Menurut Gardner (dalam suparno, 2004:28) kecerdasan logis matematis adalah kemampuan seseorang yang berkaitan dengan penggunaan bilangan dan logika secara efektif. Orang yang mempunyai kecerdasan ini sangat mudah membuat klasifikasi dan kategorisasi dalam pemikiran serta cara kerja mereka bekerja. Jika seseorang memiliki kecerdasan logis matematis yang menonjol ia dapat melakukan tugas memikirkan sistem-sistem yang abstrak, seperti matematika dan filsafat. Kebanyakan para filusuf dan ahli matematika.

c. Kecerdasan Musikal

Gardner (dalam suparno 2004:36) menjelaskan kecerdasan musikal sebagai kemampuan untuk mengembangkan, mengekspresikan, dan menikmati bentuk-bentuk musik dan suara. 


\section{Ach Syaikhu}

Kecerdasan musikal adalah kemapuan mengenali pola nada, tinggi rendahnya nada, melodi, dan irama, ditambah dengan kepekaan dalam menangkap aspek-aspek bunyi dan musik secara mendalam atau penuh perasaan anak-anak yang memiliki kecerdasan musikal yang baik memiliki sensitivitas untuk mendengarkan pola-pola, bersenandung, dan dapat memainkan sesuai dengan irama, maupun mebedakan bunyi-bunyi.

\section{d. Kecerdasan Spasial}

Bagi gardner kecerdasan ruang adalah kemampuan untuk menangkap dunia ruangvisual secara tepat, seperti kemampuan yang dimiliki oleh aristek, navigator dan dekorator. Orang yang memiliki kecerdasan ini mampu mengenal bentuk dan benda secara tepat, melakukan perubahan suatu benda dalam pikirannya dan mengenali perubahan itu, menggambarkan suatu hal/benda dala pikiran dan mengubahnya dalam bentuk nayata, serta mengungkapkan data dala suatu grafik. Juga kepekaan terahadap keseimbangan, relasi, warna, garis, bentuk dan ruang. (Gardner dalam Suparno, 2004:31)

\section{e. Kecerdasan Kinestetik}

Kemapuan menggunakan tubuh atau gerak tubuh untuk mengekspresikan gagasan dan perasaan seperti pada aktor, atlet, penari, dan pemahat. Termasuk keterampilan koordinasi dan fleksibilitas tubuh. Orang yang memiliki kecerdasan kinestetik mudah mengungkapkan diri dengan gerak tubuh. Mengekspresikan pikiran dan perasaan dengan gerak tubuh, dengan tarian, memainkan drama, dan olahraga. (Gardner dalam Suparno,2004:34-35)

\section{f. Kecerdasan Interpersonal}

Kecerdasan interpersonal adalah kemampuan untuk mengerti dan peka terhadap perasaan, watak, dan temperamen orang lain. Kepekaan akan ekspresi wajah, suara, isyarat dari orang lain juga termasuk dalam intelegensi ini. Orang yang memiliki kecerdasan ini biasanya sangat mudah bekerja sama dengan orang lain dan mudah berkomunikasi dengan orang lain. (Suparno, 2004:38)

\section{g. Kecerdasan Intrapersonal}

Kecerdasan intrapersonal adalah kemampuan seseorang yang berkaitan dengan pengetahuan akan diri sendiri dan kemampuan untuk bertindak secara adaptif berdasar 
pengenalan diri. Orang yang menonjol dalam kecerdasan intrapersonal biasanya memiliki konsentrasi yang baik dan mengekspresikan perasaan-perasaan mereka yang berbeda dengan tenang.

h. Kecerdasan Naturalis

Kecerdasan naturalis adalah keahlian mengenali dan mengategorikan spesies yaitu flora dan fauna di lingkungan sekitar, mengenali keberadaan spesies, memetakan hubungan antar spesies. Kecerdasan ini juga meliputi kepekaan pada fenomena alam lainnya (misalnya:formasi awan dan gunung-gunung), dan bagi mereka yang dibesarkan di lingkungan perkotaan, kemampuan membedakan benda tak hidup, seperti mobil, sepatu karet, dan sampul kaset cd, dan lain-lain menurut Gardner (dalam Yuliani, 2011: 194). Kecerdasan Naruralis juga dapat diartikan kemampuan merasakan bentukbentuk serta menghubungkan elemen-elemen ada di alam.

i. Kecerdasan Eksistensial

Gardner mulai mengungkapkan tentang kemungkinan adanya jenis kecerdasan yang kesembilan, yaitu kecerdasan eksistensial. Kecerdasan merupakan kecerdasan yang menaruh perhatian pada masalah hidup yang paling utama. Kecerdasan eksistensial adalah kemapuan untuk menempatkan diri dalam lingkup kosmos yang terjauh dengan makna hidup, makna kematian, nasib dunia jasmani dan jiwa, makna pengalaman mendalam tentang cinta dan seni. (Naisaban, 2004:181)

\section{Strategi Pembelajaran}

Strategi Pembelajaran Berbasis Multiple Intelegences

Strategi pembelajaran multiple intelegences adalah suatu cara mengakses informasi melalui delapan jalur kecerdasan yang ada pada masing-masing siswa, namun untuk mengeluarkannya kembali seluruh kecerdasan bersinergi dalam satu kesatuan unik sesuai dengan kebutuhan (Amstrong dalam Alamsyah, 2016: 31). Pembelajaran berbasis kecerdasan jamak harus di integrasikan dalam satu kegiatan, Karena sejatinya anak memiliki presentase jenis kecerdasan yang berbeda-beda, dimana nantinya stimulus dari setiap kecerdasan akan berbeda pula. Oleh karena itu dibutuhkan strategi pembelajaran yang kreatif guna menyalurkan seluruh kecerdasan anak dalam satu kegiatan. 
Ach Syaikhu

KegiatanpembelajaranMultiple Intelegences menitik beratkan padasiswa belajar aktif. Menurut Dee Fink (dalamAlamsyah, 2016:32) menyatakan bahwa pembelajaran siswa aktif (active learning) adalah suatu proses pembelajaran untuk memberdayakan peserta didik agar belajardengan menggunakan berbagai cara/ strategisecaraaktif. Cara kerja otak mempengaruhi pembelajaran aktif anak yang berbasis multiple intelegences.

1. StrategiPembelajaran di Taman Kanak-kanak

Terdapat tujuh strategi pembelajaran khusus yang dapat dijadikan dasar untuk merencanakan dan melaksanakan kegiatan pembelajaran pada Pendidikan Anak Usia Dini, menurut Kostelnik (dalam Masitoh, 2011:7.17)

a. Kegiatan Eksploratori

Melalui kegiatan eksploratori ini, anak diharapkan dapat melakukan banyak kegiatan eksplorasi terhadap lingkungan, baik dengan benda, binatang, tanaman, manusia atau dengan peristiwa. Sehingga anak dapat membangun pengetahuannya sendiri kemudian dapat mengembangkan kemampuan berpikirnya dari berpikir konkret menuju berpikir abstrak. Dalam kegiatan eksporasi ini anak akan memilih kegiatan yang sesuai dengan keinginan atau minatnya. Menurut Tylor (dalam Masitoh, 2011:7.18), melalui kegiatan eksplorasi memungkinkan anak dapat mengembangkan penyelidikan langsung melalui langkah-langkah spontan, belajar membuat keputusan apa yang akan dilakukan, bagaimana cara melakukannya dan kapan melakukannya. Meskipun anak-anak adalah kunci atau peran utama dalam kegiatan belajarnya, tetapi dalam kegiatan ekplorasi ini, peran guru juga sangat penting untuk mendorong perkembangannya. Guru harus berusaha untuk memberikan fasilitas untuk anak, seperti menyediakan bahan-bahan dan peralatan bermain yang diperlukan sehingga anak akan merasa tergugah untuk terlibat aktif dalam kegiatan ekploratori ini. Oleh karena itu, guru harus benar-benar merencanakan yang matang.

b. Penemuan Terbimbing

Tujuan dari penemuan terbimbing bagi anak- anak adalah agar anak-anak dapat membangun hubungan dan konsep melalui interaksi dengan benda dan manusia. Penemuan terbimbing ini harus memusatkan pada proses belajar anak bukan pada hasil yang dicapainya. Proses berpikir anak-anak dijadikan dasar untuk merencanakan pengalaman belajarnya, dimana melalui 
pengalaman tersebut anak secara bertahap akan membangun konsep yang lebih tepat bagi dirinya sendiri. Disini peran guru yakni menyediakan alat dan informasi yang diperlukan, yang dapat mendukung kemajuan belajar anak melalui pengembangan kemampuan yang berkaitan.

\section{c. Pemecahan Masalah}

Melalui strategi pembelajaran pemecahan masalah ini, anak-anak dapatmerencanakan, meramalkan, mengamati hasil-hasil tindakannya. Masalah yang baik untuk dapat dipecahkan bagi anak yakni masalah yang berkaitan dengan dirinya sendiri melalui berbagai cara. Dengan masalah-masalah yang dikenal oleh anak, maka anak dapat lebih mudah untuk memecahkan masalah tersebut serta anak dapat merumuskan kesimpulannya, menurut Goffin dan Tull (dalam Masitoh, 2011:7:20)

d. Diskusi

Strategi pembelajaran diskusi adalah metode yang menunjukkan interaksi timbal balik antara guru kepada anak, anak kepada guru atau anak kepada anak yang lainnya. Peran guru dalam strategi pembelajaran yakni mendorong peserta didik untuk mengemukakan gagasannya sendiri, mengkomunikasikan dan mengembangkan gagasan tersebut secara luas kepada guru atau temannya. Adapun topik yang dapat dikembangkan menjadi diskusi bagi anak misalnya kejadian-kejadian disekolah, peristiwa yang terjadi di lingkungan.

e. Belajar Kooperatif

Strategi pembelajaran kooperatif adalah yang melibatkan anak-anak untuk bekerja sama dalam kelompok dan setiap anak dapat berpartisipasi dalam tugas-tugas bersama yang diarahkan langsung oleh guru, menurut Cohen (dalam Masitoh, 2011:7:24). Peran anak dalam belajar kooperatif ialah anak akan belajar bersama-sama melakukan tugas berperan sebagai teman sejawat dan mentor bagi anak lainnya, sedangkan guru bertanggung jawab penuh belajar kooperatif ini dapat mencapai tujuan pendidikan dan guru juga harus mampu mendorong pesrta didiknya untuk belajar bersama-sama. Menurut Harmin (dalam Masitoh, 2017:7:25) menjelaskan tentang jumalah anggota dalam setiap kelompok hendaknya tidak lebih dari tiga atau empat orang. Karena jika lebih dari jumalah tersebut, pembelajaran akancenderung menghasilkan partisipasi yang pasif. 
Ach Syaikhu

f. Demonstrasi

Strategi pembelajaran demonstrasi merupakan bentuk penyajian pengetahuan dan ketermapilan tertentu kepada anak. Dengan strategi pembelajaran demonstrasi ini, guru akan lebih mudah untuk menyampaikan pengetahuan dan keterampilan bukan hanya dengan penjelasan saja. Menurut Kostelnik, ada tiga langkah strategi demonstrasi yakni: (1) Meminta perhatian anak, (2) menunjukkan sesuatu kepada anak, (3) meminta tanggapan anak terhadap apa yang mereka lihat.

g. Pengajaran Langsung

Pengajaran langsung adalah strategi pembelajaran yang digunakan untuk membantu anakanak mengenal istilah-istilah, strategi, informasi factual dan kebiasaan-kebiasaan, menurut Driscoll (dalam Masitoh, 2011:7:27). Dalam pengajaran langsung, peran guru sangatlah besar untuk memadukan pe,belajaran yang tepat sesuai waktu yang disediakan dan mengarahkan anak-anak melalui langkah-lamgkah yang jelas, sehingga anak dapat memberikan renspon yang relatif tepat.

\section{Strategi Mengajar Berbasis Multiple Intelligences}

1. Strategi Mengajar Kecerdasan Naturalis

Menurut Saripudin (2017:15-16) Kecerdasan naturalis pada anak usia dini dapat dikembangkan melalui berbagai cara.Adapun strategi yang dilakukan adalah sebagai berikut:

a. Mencari batu-batu unik, misalnya mencari jenis batu tertentu dengan ciri batu yang berbedabeda dari batu yang halus, kecil, berwarna putih atau hitam, batu yang tajam, batu yangbesar.

b. Bereksperimen dengan rumput yaitu dengan cara menyediakan selembar kain/sisa bekas,potong berbentuk huruf atau angka. Kain tersebut di letakkan dihalaman yang di tumbuhirumput, selanjutnya kain ditusukkan ke rumput dengan menggunakan tusukan gigi supaya tidak bergerak. Setelah satu minggu anak diajak melihat potongan kain tersebut dan apa yang terjadi, yaitu tampak gambar yang sama dengan pola potongan kain. Permainan ini disebut proses fotosintesis. Rumput yang ditutupi potongan kain tidak mendapat 
cukupmatahari sehingga tidak bisa berfotosintesis, tidak bisa mengolah makanan, sehinggadaunnya berwarna hijau muda(kuning karena layu), seharusnya berwarna hijau tua.

c. Pergi ke museum yang berkaitan dengan alam, seperti ke museum geologi, museum ilmupengetahuan alam dan sebagainya. Untuk mendapatkan informasi tentang kondisi alam,jenis binatang, ragam tumbuhan di masa lalu. Anak bisa mengetahui anatomi tubuh manusiamaupun binatang, proses-proese biologi dan sebagainya. Aktivitas ini akan mengasah dayakritisnya terhadap masalah lingkungan.

d. Bereksperimen dengan bunga yaitu dengan cara menyediakan empat batang bunga sedapmalam, atau bunga lain yang berwarna putih dan batangnya mempunyai pori-pori besar.Masukkan batang bunga tersebut ke dalam gelas yang sudah berisi air yang berwarnakuning, merah dan biru, serta satu gelas yang berwarna putih. Diamkan semalam, dan lihatkeesokan harinya, anak pasti terkejut karena tiga batang bunga yang semula berwarna putihbrubah berwarna kuning, merah dan biru, dan satu yang tetap berwarna puith. Melaluipermainan ini, memberikan pengalaman kepada anak proses tumbuhan menyerap air.

e. Menanam bunga yaitu mengajak anak menanam bunga, sayur atau buah, dengan tanamanyang aman untuk anak yaitu yang tidak berduri, tidak berbulu, tidak berdaun kasar,tidakmengandung racun dan sebagainya. Pilih tanaman yang cepat berbunga atau berbuah,misalnya menanam tomat, strawberry, ketimun, wortel, aneka bunga, dan sebagainya.Dalam proses menanam, ajak anak untuk mengukur tinggi tanaman, menghitung jumlahdaun, menghitung jumlah bunga, dan sebagainya. Aktivitas ini memberikan pemahaman mengenai berhitung, dan cara mengukur tinggi, yang meningkatkan kecerdasan logismatematisnya. Mengembangkan motorik kasarnya, melatih kesabaran serta tanggung jawab.

f. Pelihara binatang yaitu dengan memelihara binatang yang mudah perawatannya dan tidakmembahayakan anak, contohnya kelinci, ikan, hamster, kura-kura dan sebagainya. Ajakanak untuk memberi makan binatang dan saat memberikan kandang / kolam. Bila anaksudah bisa memberikan makan binatang peliharaannya secara mandiri, bantu anak untukmembuat jadwal memberi makan binatang, dan berlatih untuk mematuhi jadwal 
Ach Syaikhu

tersebut.Aktivitas ini akan mengasah empati anak terhadap binatang serta melatihnya tanggungjawab.

2. Strategi mengajar Kecerdasan Linguistik

Kecerdasan linguistic adalah kecerdasan yang paling mudah untuk mengembangkan strategistrategi, karena begitu banyak perhatian telah diberikan bagi pengembangannya di sekolahsekolah (Amstrong, 2013: 80).Berikut ini beberapa strategi pembelajaran yang dapat melibatkan kecerdasan linguistik.

a. Ceramah

Ceramah adalah pidato yang dilakukan oleh seseorang di hadapan banyak pendengar guna memberikan pengetahuam mengenai sesuatu hal dan lain sebagainya. Idealnya pembelajaran multiple intelegencer berbasis ceramah tetap menitik beratkan pada kemampuan anak dalam penyampaian inti gagasan materi atau inti sari materi yang sudah diajarkan oleh guru, namun sampai saat ini metode ceramah digunakan sebagai bahan penyampaian materi oleh guru tanpa melibatkan siswa dalam kegiatannya. Dengan hal itu, siswa tidak dapat bersikap aktif dan merasa jenuh dalam menjalani proses pembelajaran.

Adapun prosedur penerapan strategi ceramah menurut (Andi, 2016:34) adalah sebagai berikut: (1) guru menyiapkan intisari/ poin penting dari materi yang ingin disampaikan kepada siswa. Poin materi dapat dibuat dalam bentuk potongan kertas yang nantinya poin dari materi tersebut akan dikembangkan oleh anak. (2) sebelum melibatkan keaktifan anak, guru harus memberikan materi ajar kepada anak secara interaktif, sehingga anak mampu mengembangangkan poin materi yang telah diberikan oleh guru. (3) pemberianmateri ajar diberikan pada pertemuan sebelumnya. (4) guru harus menyiapkan lembar penilaian agar guru mampu mengukur kemampuan anak dengan mudah, ada dua metode ceramah menurut andi, yaitu penilaian antar sesame siswa dan penilaian yang dilakukan guru. (5) setelah ceramah selesai, kita dapat meminta anak untuk menceritakan atau menuliskan hal baru yang didapat saat metode ceramah yang diberikan guru sebelumnya. (6) beri waktu untuk anak menyampaikan hasildari proses belajranya dan sebaiknya guru tidak memberi batasan waktu untuk anak bercerita.

68 | Jurnal Auladuna 
3. Strategi Mengajar Kecerdasan Logis-matematis

Kecerdasan logis matematis sering kali dipatokkan pada kemampuan dalam mata pelajaran matematika dan ilmu pengetahuan alam saja, padahal kecerdasan ini jga berlak pada sema dimensi penetahuan, termasuk ilm sosial dan ilmu humaniora. Strategi logis matematis jga dapat digunakan dalam pembelajaran sosial, olahraga, agama, seni, kerajinan tangan bahkan jga pendidikan kewarganegaraan (Alamsyah, 2016:112). Pembelajaran logis matematis dapat diterapkan pada siswa-siswa yang memiliki kecenderungan pada kecerdasan numerik. Pendekatan logis matematis memiliki dasar yang menekankan pada kegiatan bersifat kuantitatif, terukur, dan analisis. Dalam pembelajarannya,pendekatan ini menekankan pada kemampan mengurutkan, penalaran, berpikir dalam pola sebab akibat.

Salah satu contoh strategi pembelajaran logis matematis adalah strateg klasifikasi. Klasifikasi adalah pengelompokkan premis-premis berdasarkan kriteria, ciri-ciri, dan indikator tertentu (Alamsyah, 2016:126). Strategi klasifikasi adalah aktivitas pembelajaran menggunakan kegiatan cara pengelomppokan bebrapa data kedalam minimal dua area atau premis yang mempunyai kriteria, ciri-ciri, dan indikator tertentu menrut Chatib (dalam Alamsyah, 2016:127).

Adapun prosedur aktivitas strategi klasifikasi dapat dilakukan dengan membagi kelompok siswa sesuai dengan jumlah area atau premis. Prosedur penerapan strategi ini didasarkan pada tiga hal: pertama, banyakna data yang disebar, kedua, area, dan ketiga, pencocokan antara data dan area (Chatib dalam Alamsyah, 2016:127). Berikul hal yang perl diperhatikan dalam penerapan strategi klasifikasi:

a. Guru mengumpulkan data-data yang telah disebar (data biasanya berbentuk potongan kalimat atau potongan gambar). Setiap data memiliki pernbedaan dana prsamaan masing-masing.

b. Guru menentukan area klasifikasi. Area klasifikasi dapat lebih dari dua area. Tugas siswa adalah mengklasifiksikan/mengelompokkan data-data kedalam sebuah area.

c. Guru menyiapkan lembar kalsifikasi ang akan diisi oleh siswa dalam melakukan klasifikasi/pengelompokkan.

Strategi klasifikasi bisa diterapkan pada sema jenjang pendidikan, khususnya di jenjang anak sia dini. Strategi pembelajaran ini melibatkan keaktifan siswa, oleh karena itu strategi ini 
Ach Syaikhu

dikategorikan pembelajaran aktif (active learning). Strategi pembelajaran klasifikasi ini berkaitan erat dengan berpikir analisis, yaitu menemukan kategori dengan mengelompokkan premis yang sama (matematis-logis). Kegiatan pembelajaran ini dilakukan dengan basis kelompok (interpersonal) dan menggnakan data spasialvisual berupa potongan gambar. Menurut (Alamsyah, 2016: 128) Inti pendekatan multiple intelegnces strategi klasifikasi adalahmatematis-logis, adapn modalitas belajar ang dignakan pada aktivitas klasifikasi adlah visual kinetetik.

4. Strategi Mengajar Kecerdasan Spasial-Visual

Pembelajaran multiple intelegences memiliki dasar ang menekankan pada pembelajaran aktif, beberapa pendekaan harus melibatkan siswa dalam proses pembeljarannyabkan hana sekadar memberikan informasi kepada mereka ntuk diterimanya. Pemvelajaraan menggunakan gambar pada anak usia sekolah telah terbukti dari hasil riset. Para ahli otak menyatakan bahwa 65\% anak adalah pembelajar visual. Informasi visal akan diterima 65 ribu kali lebih cepat oleh otak dari pada menggunakan teks. Mengajar menggnakan pendekatan kecerdasan spasial visual memungkinkan proses input pengetahan terjadi pada lobus bagian belakang. Hemisphere kanan, lobus oksipital, dan bagian posterior belahan kanan. Lobus oksipital berkaitan dengan penglihatan..

Salah satu pembelajaran yang bisa dignakan untk penmbelajaran berbasis spasial visual adlah pembeljaran menggunakan flash card. Flash card dalam bahsa indonesia disebut kartu pembelajaran. Strategi ini bisa diterapkan dengan cara bermain. Permainan ini dapat digunakan pada seluruh bidang studi mapun tematik studi. Flash card digunakan sebagai media pembelajaran oleh guru melalui aktivitas permainan. Siswa melakukan kegiatan dengan flash card sesuai dengan arahan guru. Aktivitas pembelajaran flash card dapat mempermudah siswa untuk memahami suatu materi pelajaran yang dianggap rumit. Penggunakaan gambar pad pembelajaran akan mudah ntk diingat oleh siswa.

Penggunaan strategi flash card hars disesuaikan dan dikelompokkan dengan temayang telah dibuat, selain itu ukuran dari flash car disahakan satu flash card diisi satu gambar agar flash card terlihat jelas. Berikut prosedr penerapan strategi flash card menrut Alamsyah:

a. Guru membuat flash card dari bahan bekas.

70 | Jurnal Auladuna 
b. Flash card dibuat dari kards agar lebih kuat, namun dapat jga dibat dari bahan karton. Agar gambar terihat menarik maka gambar pada flashcard di cetrak secara berwarna.

c. Sebelum memlai permainan flash card, trleebih dul guru menjelaskan teknis dan aturan permainan.

d. Aktivitas belajar siswa saat mencari pasangan flash card dilakkan tanpa suara. Namun dilakkan dengan kode tertenu. Kode jempol jika siswa menemukan pasangan flash card dengan tepat.

Strategi pembelajaran flash card ini sudah sering diterapkan pad jenjang anak usia dini. Penilaian proses pemblajaran siswa menggnalkan strategi ini dikategorikan dari oenilaian unjuk kerja (performence). Penilaian unjuk kerja menekanpada pad proses kerja, sehingga mekanisme penilaianna menggnakan rubrik.

5. Strategi Mengajar Kecerdasan Musikal

Menurut Gardner kecerdasan msikal merpakan bentuk bakat manusia yang paling awal mnck gardner menatakan bahwa keahlian dibidang musi bergantung pada bertambahnya pengalaman hidup seseorang. Dikutip dari live science, bahwa musik mempengaruhi otak dengan cara luar biasa ketika seseorang sedang mendengarkan live musik. Siswa ang melakukan apersepsi sebelum belajar, otaknya akan terkondisi pada frekuensi 8-13 hertz, artinya otak siswa berada dalam kondisi alpa, yaitu suat kondisi rileks, santai dan memikirkan jalan keluar terhadap suat maslah dan siap mempelajari suatu materi (Said dalam Alamsyah, 2016).

Salah satu strategi dari kecerdasan musikan adalah kemampuan bernyanyi. Bernyanyi adalah aktivitas belajar ang menggnakan lagu, baik secara berkelompok maupn individu. Guru dapat memaskkan materi ajar kedalam sebuah lagu. Tidak semua siswa menukai bernyanyi, namun banak juga siswa ang merasa $\mathrm{m} \backslash$ naman dan lebih mudah memahami materi dengan cara bernyanyi. Pembelajaran pada anak usia dini tidak luput dari pembelajaran bernanyi, karna bernanyi aktivitas bernani pada anak sia dini mamp meringankan otak anak ntuk menerima kegiatan belajar secara riang.

6. Strategi Mengajar Kecerdasan Kinestetik 
Ach Syaikhu

Menurut Lwin, 2003: 135, mendefinisikan kecerdasan kinestetik sebagai kemampuan dalam mengorganisasi gerak anggota tubuh dengan pikiran secara serentak untuk mencapai tujuan yang diinginkan. Peserta didik dengan kecerdasan kinestetik yang tinggi cenderung lebih aktif dibanding peserta didik lainnya. Strategi mengajar kecerdasan majemuk pada peserta didik dengan kecerdasan kinestetik yang dominan, antara lain:

a. Membiasakan peserta didik untuk menanggapi materi yang sedang dipelajari dengan respon tubuh tertentu. Misalnya, anggukan kepala jika mengerti atau mengernyitkan dahi jika mengalami kebingungan.

b. Mendramakan materi yang sedang dipelajari. Strategi ini akrab disebut bermain peran atau teater kelas.

c. Pendidik menegaskan suatu konsep melalui ilustrasi fisik atau bisa dengan meminta peserta didik melakukan gerak pantomim.

d. Membuat prakarya untuk menggambarkan suatu benda atau peristiwa. Misalnya, membuat miniatur rumah joglo.

e. Mempelajari suatu materi menggunakan "peta tubuh". Strategi ini mengasosiasikan materi pelajaran dengan anggota tubuh. Misalnya,pada materi struktur pohon pendidik mengasosiasikan kaki sebagai akar, perut dan dada sebagai batang, tangan sebagai cabang, jari sebagai ranting, dan rambut kepala sebagai daun.

7. Strategi Mengajar Kecerdasan Intrapersonal

Kecerdasan intrapersonal bersifat genetis. Namun, pengalaman dan lingkunganlah yang akhirnya menentukan kualitas kecerdasan intrapersonal. Kecerdasan intrapersonal bisa dibangun oleh interaksi hubungan sosial dan lingkungannya sehingga memperkaya pengalaman pribadi seseorang.

Ada beberapa strategi mengajar yang harus dilakuan oleh guru dalam membantu mengembangkan kecerdasan intrapersonal, yaitu dengan bercakap-cakap, pemberian tugas memotivasi diri, bercakap-cakap mengenal dan mengungkapkan perasaan, mengenal berbagai ekspresi dari perasaan, keyakinan diri, mengagumi diri sendiri, mengendalikan emosi.

\section{Bercakap-cakap}

72 | Jurnal Auladuna 
Mengenal cita-citaku (anak diberi serial gambar tentang berbagai profesi seperti dokter, guru, pilot, polisi, petani, penyanyi, pedagang, dll kemudian anak ditanya "Besok kalau besar pengen jadi apa?), Mengenal dan mengungkapkan perasaan.

\section{Pemberian Tugas Memotivasi Diri}

Anak diminta untuk melakukan suatu kegiatan dengan sejumlah rintangan, misalnya rintangan yang pertama berjalan naik tangga, rintangan kedua langsung turun dengan merosot di perosotan, setelah turun langsung berjalan melewati terowongan atau lorong, setelah melewati terowongan berjalan melewati dua kali rintangan lagi dengan melompat tali karet yang di ikatkan di bagian perut anak sebelah kanan dan sebelah kiri, Setiap kali anak berhasil melampaui rintangan, dia diperbolehkan mengambil bendera kecil yang ada di atas meja yang sudah disediakan guru. Semakin besar motivasi anak untuk mengatasi rintangan dan berhasil mengatasinya, semakin banyak bendera yang dapat dikumpulkan. Apabila ada anak-anak lain, mereka diminta melakukannya secara bergantian, sementara yang lain menunggu giliran dapat diminta bersorak-sorak untuk memberikan dukungan. Melalui kegiatan ini anak dapat dilatih untuk memotivasi diri.

3. Bercakap-cakap mengenal dan mengungkapkan perasaan

Pada intinya, kecerdasan intrapersonal memberikan wawasan agar anak menjadi diri sendiri, bukan membuat diri sendiri menjadi orang lain. Pada dasarnya kecerdasan intrapersonal mengajak anak untuk harus percaya pada diri sendiri.

\section{Strategi Mengajar Kecerdasan Interpersonal}

Menurut Lwin, 2003:197, mendefinisikan kecerdasan interpersonal sebagai kemampuan dalam menjalin hubungan dengan orang lain atas dasar pemahaman dan tanggapan yang tepat terhadap maksud dan perasaan orang lain. Peserta didik dengan kecerdasan interpersonal yang tinggi mudah dikenali karena selalu dikelilingi oleh teman yang banyak dalam kesehariannya.

Ada beberapa strategi mengajar yang harus dilakuan oleh guru dalam membantu mengembangkan kecenderungan kecerdasan interpersonal, yaitu dengan:

a. strategi kerja kelompok atau belajar kelompok

b. saling berbagi rasa antara teman 
Ach Syaikhu

c. kerja sama

d. negosiasi

e. belajar melalui interaksi dengan orang lain, belajar melalui kolaborasi dan dinamika kelompok.

\section{c. Penutup}

Strategi pembelajaran multiple intelegences adalah suatu cara mengakses informasi melalui delapan jalur kecerdasan yang ada pada masing-masing siswa, namun untuk mengeluarkannya kembali seluruh kecerdasan bersinergi dalam satu kesatuan unik sesuai dengankebutuhan. Strategi pembelajaran berbasis multiple intelligences lebih menitik beratkan pada keunikan yang dimiliki oleh peserta didik. Multiple intelligences juga menganggap tidak ada anak yang bodoh, melainkan setiap anak itu cerdas dengan kelebihan kecerdasan masing-masing. Strategi Pembelajaran Multiple Intelegensi pada praktinya adalah memacu kecerdasan yang menonjol pada diri siswa supaya optimal Sependapat dengan Gardner, kecerdasan ada 8 macam yaitu: Kecerdasan linguisti, Intelegensi logis-matematis, Intelegensi Musik, Intelegensi kinestetik, Intelegensi Visual-Spasial, Intelegensi Interpersonal, Intelegensi Intrapersonal, Intelegensi Naturalis.

74 | Jurnal Auladuna 


\section{DAFTAR PUSTAKA}

Alamsyah, Andi. 2016. Strategi Mengajar Multiple Intelegences Mengajar Sesuai Kerja Otak dan Gaya Belajar Siswa). Jakarta: Prenadamedia Group

Imami, Fildza. 2018. Strategi pembelajaran anak usia dini berbasis multiple intellegences. Wonosobo. Mangku Bumi.

Lwin, M. et al. 2008. Cara Mengembangkan Berbagai Metode Komponen Kecerdasan: Panduan Praktis bagi Guru, Masyarakat Umum, dan Orang Tua. (Alih Bahasa Christine Sujana). Jakarta: Indeks.

Masitoh, dkk. 2011. Strategi Pembelajaran TK. Jakarta: Universitas Terbuka.

Nasiban, Laddiaus. 2004. Para Psikologi Terkemuka Dunia: Riwayat Hidup, Pokok Pikiran, Dan Karya. Jakarta. Gramedia Widiasarana Indonesia.

Saripudin, Aip. 2017. Strategi Pengembangan Kecerdasan Naturalis Pada Anak Usia Dini.Jurnal Pendidikan Anak. 3(1): 15-16

Suparno, Paul. 2004. Teori Inteligensi Ganda Dan Aplikasinya Di Sekolah. Yogyakarta. Kanisius. Yuliani. 2011. Konsep Dasar Pendidikan Anak Usia Dini. Jakarta: INDEKS. 